DOI: $10.15503 /$ jecs20142.223.236

\title{
EDUCATION FOR SUSTAINABILITY IN POLAND - A NARRATIVE LITERATURE REVIEW
}

\author{
MAGDA SCROBOTA \\ Malmö University, 20506 Malmö, Sweden \\ Email address:
}

\begin{abstract}
As a member state of the European Union, Poland is committed to sustainability by endorsing the principles of sustainable development in its Constitution and adopting European standards. However, to overcome the societal, environmental and economic demands, a society needs to integrate sustainability concepts into daily practices, education playing a crucial role in achieving this objective. This paper aims to provide an overview of the education for sustainability in Poland and its impact on Polish society. Designed as a narrative literature review, the paper reports on how education for sustainability was carried out between 1994 and 2013, building a detailed picture of the educational programs and actions conducted in business and non -profit organizations. Additionally it is revealed that although challenging, creating community-based learning can increase people's awareness and potential to contribute to a sustainable future by reducing the de-coupling effect between organizational actual practices and declarations.
\end{abstract} review

Keywords: sustainability, sustainable development, education, Poland, de-coupling effect, literature

\section{INTRODUCTION}

The concept of sustainability emerged as a response to the most stringent problems of humanity. Defined for the first time in the Brundtland report published by the World Commission on Environment and Development in 1987 as the "development which meets the needs of the present without compromising the ability of future generations to meet their own needs" (United Nations, 1987, p. 15), sustainable development makes the main topic for the Conference on Environment and Development in Rio de Janeiro, in 1992. The conference distinguishes itself in the world of academia by establishing the principles of sustainable development and the indisputable relation between the three fundamental pillars: environmental protection, social equity and economic development (Scrobota \& Vosylius, 2013). 
While the model sounds irrefutable in theory, it has proven to be challenging to implementation and explanation in practice. Because of the many understandings and meanings of sustainability as a term, it can become difficult to adopt the principles of sustainability at local and global levels (Sendzimir, 2010). It is where the role of such organizations as United Nations becomes crucial in addressing these challenges and raising awareness at a global level. Committed to its purpose of creating a sustainable future, The United Nations started the journey into the Decade of Education for Sustainable Development (2005-2014), defining the education for sustainable development as the umbrella for many forms of education which includes "key sustainable development issues into teaching and learning; for example, climate change, disaster risk reduction, biodiversity, poverty reduction, and sustainable consumption" (2012, p. 2) Addressed to a wide variety of people, education for sustainable development stands for the multitude of programs taken to help each individual to discover his/her potential and path into sustainability. As we enter into the final stage of the Decade of Education for Sustainable Development, it is worth mentioning that more than 100 countries have developed organizations to conduct and foster programs for education for sustainability, achieving visible results for the sustainable development (United Nations, 2012).

Poland is no exception as it has consolidated its position towards sustainability by endorsing it in the Constitution since 1997: "The Republic of Poland guards independence and inviolability of its territory, ensures freedoms, human and citizen's rights and the safety of citizens, guards the national heritage and ensures the environmental protection driven by the sustainable development principle" (The Constitution of the Republic of Poland, chapter I, article 5, p. 2) and adopting a proactive attitude in dealing with challenges of sustainable development. UNESCO member state since 1946 and member of the European Union since 2004, Poland has conducted educational programs for ecology and environmental protection for more than 20 years, participating in the European environmental initiatives and confirming the harsh reality that implementing sustainability can be a complicated process when an intertwined network of factors ought to be considered: existing pressure from institutions, psychological and physical structures in society (Sendzimir, 2010). In spite of the increased number of studies, publications and reports on sustainability practices existing in Poland from recent years (Koscielniak, 2014; Czapla \& Berlińska, 2011; Smith \& Jehlicka, 2013; Pawłowski, 2013), little has been investigated about education for sustainability and its generated impact on Polish society. This paper aims to address this research gap by building a detailed picture of the educational programs and actions conducted in business and non-profit organizations, answering the following research questions: How education for sustainability has been carried out in Poland between 1994 and 2013? and What is the impact created by education for sustainability on Polish society?

\section{POLAND IN THE CONTEXT OF SUSTAINABILITY}

Poland has gone through a course of demanding events from a socialist type of economy to a market one, integrating the European standards into daily policies. Although the overall interest in development is present, it has highlighted the socio-economic development the the detriment of the environmental development 
concerning stringent problems such as: pollution, waste management, water quality, resource exploitation and depletion. As a consequence of low financial sources, the "trans-boundary and global environmental problems are likely to be less important" (Platje, 2011, p. 110) in the process of EU accession. As stated by de la Motte (2007) the environmental problems have a root cause in a state-centered and technocratic policy which frequently is lacking the effective transparency of the public authorities.

Since education for sustainable development is enabling people to know the consequences of their actions and how they can contribute to a more sustainable future, it is evident that institutions play a substantial role in changing people's mindsets. Therefore, a lack of institutional capital would generate difficulties in adopting sustainable practices (Platje, 2011).

One of the guiding documents into the Polish approach to sustainability is the Poland 2025: Long-Term Strategy for Sustainable Development. This document provides a long-term multidimensional strategy for the sustainable development which is described as "a process that allows for a gradual balancing of growth, social cohesion and environmental protection" (Zieschank, 2004, p. 4). The strategy is developed around three parts: visions, goals and political premises for sustainable development, policy fields and measurements in relation to the triple bottom line elements and monitoring stage.

Moreover, the document Poland 2025 aims to constitute a framework for the other national regulatory plans and strategies, such as: The National Environmental Policy for 2003 - 2006 and Its 2010 Outlook and The National Environmental Policy for 2009- 2012 and Its 2016 Outlook.

As OECD ${ }^{1}$ (2006) recommends the strategic planning frameworks to be longterm oriented in order to become successful and to create "strong and lasting political commitment" (p. 17), Poland has assigned a special governmental body to be in charge of the entire process of sustainable development - The Board of Sustainable Development. In addition, in Poland there exist other decision-making structures responsible for addressing sustainability, such as: The National Sustainable Development Coordination Body, The National Sustainable Development Policy, The National Agenda 21 Framework, a number of Local Regional Agenda 21 Frameworks, and Environmental Impact Assessment Law (Nowaczek \& Fennell, 2002). However, despite the efforts to create a centralized system of promoting and implementing sustainability in Polish daily practices, United Nations (2009) draws attention to the decentralized educational and political systems which "allow institutions at the local level to develop their own interpretations of ESD" (p. 40). This led to an increasing number of activities across all sectors of society which requires coordination to bring them together and maximize the results. As a matter of fact, the OECD reports (2011) on Poland's achievements in implementing sustainability by emphasizing areas such as strengthening the green public and corporate procurement, enhancing of green standards, conducting energy audits. Nevertheless, objectives like "providing green entrepreneurship programs and raising awareness of the green economy" (OECD, 2011, p.16 in Koscielniak, 2014, p. 117) remain important milestones completed up to this moment.

Organisation for Economic Co-operation and Development (OECD) has a mission to promote policies that will improve the economic and social well-being of people around the world. 
For a better understanding of Poland's position in the assessment of sustainability, the SAFE system is offering the countries' index of sustainability based on fuzzy logic concepts. The model proposed by Phillis et al. (2011) takes into consideration two different types of indicators, HUMS and ECOS, in order to calculate the sustainability of countries during the study period 1990 - 2011. HUMS stands for the human sustainability including indicators like political aspects, economic welfare, health and education, whereas ECOS, meaning ecological sustainability, comprises indicators such as: water quality, land integrity, air quality and biodiversity (Grigoroudisa, Kouikogloua \& Phillis, 2013). According to this measurement method, Poland ranks 23 out of a total of 128 countries participating in the study, the ten highest-ranking countries being: Germany, Switzerland, Sweden, Norway, Finland, Denmark, Austria, Netherlands, Belgium, and France.

Referring to the Polish awareness to sustainability, recent studies reveal a lack of knowledge and understanding of the terms, due to a weak practice of integrating sustainable development into the educational system. As stated by Czapla and Berlinska (2011), only $36 \%$ of the Polish participants in the report about ecological awareness were able to define correctly the concept of sustainable development. Supporting these findings, another study points out the need for sustainability indicators as indispensable tools "for monitoring this concept of sustainable development, reflecting its essence in a measurable manner" (Czarski, 2011, p. 15). One of the most important indicators of sustainability is the education level which has the capability to reflect the social and economic transformations. In Poland the participation of adults in lifelong learning activities has a low index, "only every nineteenth adult citizen of Poland took part in further education and training" (Czarski, 2011, p. 49), when compared to results from Denmark and Sweden, where every third adult has been involved in a long term form of education, respectively every fourth one. Furthermore the need for having education for sustainability is underlined by the two environmental strategies supported by the Council of ministers in Poland, The National Environmental Policy for 2003 - 2006 and Its 2010 Outlook and The National Environmental Policy for 20092012 and Its 2016 Outlook. Both plans set clear instructions on how the environmental education should be organized: "Effective implementation of the objectives of the National Environmental Policy requires all the entities concerned who could directly or indirectly affect the methods and intensity of using the environment, including citizens' participation, to participate in this process" (Council of Ministers, 2002, p. 19) and "Education of the public is particularly important as regards pre-selection of municipal waste, as well as the promotion of and financial support to waste recovery and recycling" (Council of Ministers, 2008, p. 10).

As a member state of European Union, Poland is encouraged to develop strategies for sharing knowledge and adopting practices that foster the education for sustainability (Adomßent, M., Fischer, D., Godemann, J., Herzig, C., Otte, I., Rieckemann, M. \& Timm, J., 2014). Having received proper education, people are able to attain knowledge, values, skills and engagement so that their individual contribution makes a difference in solving the complex issues of sustainability. Education for sustainability should not be limited to the knowledge about environment, economy and society, but instead to cover a wide area of problems threatening the balance of life on the planet, offering people the opportunity to change behavior and take actions towards a sustainable future (Manitoba Education and Training, 2000; UNESCO, 2005). 


\section{METHODS}

To answer the two research questions presented in section 1 , this paper is designed as a narrative literature review. A narrative literature review summarizes primary research from which conclusions can be drawn according to reviewer's experience, existing theory and models (Campbell Collaboration, 2001; Kirkevold, 1997 in Elsevier, 2014). The contribution of a narrative literature review consists in developing understanding around various research topics, shedding light on particular aspects, offering the reader a comprehensive background of the subject in cause (Baumeister \& Leary, 1997). Compared to a systematic literature review, a narrative literature review is mainly based on the subjectivity and experience of author, usually not including a section describing the methods used in the review (Cipriani, A. \& Geddes, J., 2003; Rother, E.A., 2007). It is providing "reader with up-to-date knowledge about a specific topic or theme" (Rother, E.A., 2007, p.vii). The author relies on secondary data to provide the reader with new perspectives on the research topic, which are not always easy to identify.

Defined as the "raw data that have already been collected by someone else, either for some general information purpose or specific research project" (Blaikie, 2003, p. 18), secondary data represent the type of data used for a literature review.

To provide clarity to the study, I am explaining the selection criteria as follows: period of publication (1994 - 2014), Polish authors, key-words and phrases. The research was performed on the databases such as: Cambridge Journals Online, IEEE Xplore / IEEE/IET Electronic Library (IEL), JSTOR, Google Scholar, Oxford Journals, PsycInfo, Sage Journals, Science Direct, Springer Link, Wiley Online Library. Considering the context of the study, Polish websites of various NGOs, companies and political organizations were also included in the search. Another source for literature was represented by the discovered works in other articles or books, for which the study was expanded. Key-words and phrases played an important role in deciding which articles and publications make up the subject of the paper (Cronin, Ryan, \& Coughlan, 2008) and the search was done according to the following words and structures found in either the title or abstract of the selected studies: education for sustainability, education sustainable development in Poland, sustainable business, sustainable education, NGO and sustainability, Polish education for sustainability, Polish society and sustainability, Polish sustainability. During the research, particular care was taken on ethical considerations, all literature sources and authors being referenced accordingly to APA style, so that the intellectual property would not be infringed.

Having a qualitative insight, the paper uses the PQRS (preview, question, read, summarize) method of data analysis to facilitate the identification of themes, since a large number of publications was reviewed (Cronin et al., 2008). In addition, the "inductive process of organizing data into categories and identifying patterns (relationships) among categories" (McMillan \& Schumacher, 1993, p. 479) allows the author to look for a complexity of views and to create understanding according to her experience into sustainability and ability to identify familiar patterns. Referring to qualitative researchers, Patton (1990) is emphasizing the researcher's personal background and history considered to have an influence on his or her interpretation of the text in question. Qualitative content analysis involves the aptitude of researcher to balance personal perspective to the topics under study with an open attitude, not imputing a particular 
meaning on the text. Krippendorff (1980) claims that building themes is the vital attribute of qualitative content analysis and "a theme is a group of content that shares a commonality" (p.107).

Consequently, the analysis revealed two main themes corresponding to the research topic: education for sustainability in business organizations and education for sustainability in non-profit organizations. The next section covers the presentation and analysis of the secondary data corresponding to the previously mentioned themes.

\section{RESULTS EDUCATION FOR SUSTAINABILITY IN BUSINESS ORGANIZATIONS}

Education for sustainability represents the tool to address the challenge of creating a sustainable future for which we need "to define and understand in a concrete, substantial and just way what sustainability means" (Cortese, 1992, p. 3). As the term "education for sustainability" includes a series of other fields such as economics education, environmental education, global education, conservation education, etc. (Institute for Sustainable Communities, 2001), it is easy to observe how this type of education can become the bridge connecting business organizations to communities.

As Poland has undergone a long process of shifting from socialist to market economy, it has also adopted laws and regulations on sustainability, to both political and legal systems (de la Motte, 2007). The majority of these improvements have been made possible by using municipal funds and environmental taxes, as well as European Union funds.

However, the diagnosis of social capital in Poland $\left(\mathrm{CBOS}^{2}, 2008\right)$ shows that it is required to build civic engagement through means of education about the relationship between the condition of environment and quality of life (Sendzimir, 2010). Taking measures in this regard, the Responsible Business Forum, a non-governmental organization established in 2000, reports annually on business practices and their compliance with sustainability principles in Poland. Therefore, the report for 2010 presents companies like Alcatel-Lucent, Coca-Cola HBC Polska and Diners Club Polska as preoccupied with the welfare of their employees and improvement of their skills. Coca-Cola Poland Services is one of companies which undertook educational activities related to sustainability and ecology, in particular (Responsible Business Forum, 2010). Yet, another company, Nivea, sets an example in offering employees education regarding the work-life balance.

Educating for environment represents an increasingly visible practice in companies. According to Responsible Business Forum (2010) 17 practices concerning ecological education were identified, such as: $3 \mathrm{M}$ Poland offered education for their employees, Industria 24.pl educated on collection of waste power tools. Moreover companies such as Henkel Polska, PGNiG POOG Gazownia Bydgoska, Tesco Polska, Veolia Usługi dla Środowiska and Grupa Żywiec sponsored educational programs to improve the ecological awareness of children and young people.

One of the observed tendencies among business organizations is the initiation of co-operation with universities for research, knowledge and analysis. Companies are

2 CBOS - Public Opinion Research Center - Polish polling agency 
more likely to invest in educational programs in partnership with universities when innovative solutions are expected (Responsible Business Forum, 2010). Thus it is a win-win situation for both companies and universities. There is the example of the Wroclaw Centre for Technology Transfer (WCTT), a unit of the Wroclaw University of Technology (Politechnika Wrocławska) founded in 2011, which connects scientists with the ideas and capital of entrepreneurs, increasing the economic sustainability of the institution (Science Marketing, 2011). Since the inauguration, the center has trained over 30.000 people, offered 15.000 consultancy hours and supported approximately 350 research proposals. Following a world-wide trend, the majority of Polish companies publishes sustainability reports and presents the results achieved in this area. It is the case of RWE Polska which claims that sustainable development is an integrative part of their business (2011). In 2011, the company launched an educational campaign, "Blue RWE Current" which aimed "to show the potential of energy saving by choosing the appropriate subscription" (RWE Polska, 2011, p. 16). Another effort in improving the awareness of electricity consumption consisted in the educational program addressed to elementary schools - "Safe energy of RWE".

A similar approach regarding sustainable practices is ING, which informs about the education offered to employees in order to raise environmental awareness (2012). The company is planning to develop a communication plan to involve employees in ecological actions and to elevate employees' sensitivity to ecological solutions in their workplace.

To provide a better picture of the economic sustainability and its connection to education, Kronenberg and Bergier (2012) assess the barriers and drivers of sustainable development in Polish business, as in the following table:

\begin{tabular}{|l|l|}
\hline Drivers and barriers to sustainability in Poland as identified in literature: \\
\hline Drivers & Barriers \\
\hline Structural change & Poor institutions \\
\hline Restructuring of companies & $\begin{array}{l}\text { Low environmental and social awareness of } \\
\text { citizens and decision makers }\end{array}$ \\
\hline Competition & Entrusting PR departments with sustainability/CSR \\
\hline $\begin{array}{l}\text { New institutions in environmental policy, including } \\
\text { new economic instruments }\end{array}$ & $\begin{array}{l}\text { Few genuine good practices available among } \\
\text { Polish companies }\end{array}$ \\
\hline EU institutional pressure & Low levels of social capital and trust \\
\hline External funding & $\begin{array}{l}\text { New problems related to consumption(e.g. waste, } \\
\text { traffic) }\end{array}$ \\
\hline Foreign directinvestments & \\
\hline $\begin{array}{l}\text { External technical support(including sharing of } \\
\text { good practice) }\end{array}$ & \\
\hline Imitating good practice from abroad & \\
\hline Activity of NGOs & \\
\hline $\begin{array}{l}\text { Development of mechanisms and institutions } \\
\text { during the communist era and the transition } \\
\text { period that might support sustainable } \\
\text { development }\end{array}$ & \\
\hline
\end{tabular}

Table 1. Drivers and barriers for sustainable development in Poland. Source: Kronenberg and Bergier (2012, p. 21). 
The business cases analyzed in their study demonstrate a "low awareness in the Polish society of sustainable development problems and the role of individual consumption decisions" (Kronenberg \& Bergier, 2012, p. 21), despite the European Union perspective and adopted standards. Not having a broad experience in the domain of sustainability, Polish companies "are not particularly active in the area of either CSR or sustainability, both in the case of large companies and SMEs" (Kronenberg \& Bergier, 2012, p. 20) and the related problems are being addressed at the level of PR departments. In spite of the latest strategies and events for fostering sustainability, recent studies report an early stage of development for the sustainability reporting practices in Poland (Hąbek, 2013; Astupan \& Schönbohm, 2012).

To conclude this section, the efforts in education for sustainability at the business level have to be preceded by a strong foundation based on ethical reflection and values adopted to act in one way as opposed to another (Pawłowski, 2013). In light of these premises, the education for sustainability is more likely to have an impact on society and to generate a network of professionals specializing in sustainability who are capable of exchanging opinions, sharing knowledge and addressing crucial social challenges.

\section{EDUCATION FOR SUSTAINABILITY IN NON-PROFIT ORGANIZATIONS}

The United Nations Decade of Education for Sustainable Development (2005 - 2014) predicts that this type of education will be "implemented in thousands of local situations on the ground, involving its integration into a multitude of different learning situations" (UNESCO, 2007, p. 4). Defined as a lifelong process that enables individuals to gain creative problem-solving skills, scientific and social literacy and engage in cooperative actions (Institute for Sustainable Communities, 2001), education for sustainability has progressed in Poland due to the country's accession to the European Union.

Referring to the 1990s period studies reveal a low level of awareness of sustainability and knowledge among Polish society (Smulska, 1996 in Nowaczek \& Fennell, 2002). To balance the lack of information and to educate the public, educational programs on sustainability are expected to raise the initiative and support from local communities.

One of the earliest educational programs of such a kind was developed in 1994, addressing objectives like learning the three aspects of sustainable development - social, economic, environmental- how they are interrelated, how to communicate effectively and how to seek appropriate solutions, as well as the concept of renewable resources.

Among other earliest endeavors in education for sustainability in Poland was the program How to teach about sustainable development within "environmental education"? run by Polish educators and addressed to children of different age categories: 5-6 or 10-11-12 years of age.

To break the boundaries between education institutions and surrounding communities, there were implemented programs to teach people how they can benefit from this symbiosis (Institute for Sustainable Communities, 2001). The program called Eco-Market has taken place every Saturday since September 2001, in Podolszyce district, Plock, "providing a platform of communication between the rural and urban world" (p. 113). The program organized by the NGO: Ecological-Cultural Association "Ziarno" promotes 
organic farming, bringing together local consumers and producers, and encouraging friendly consumers' behavior in Plock. Regarding the collaboration with schools in Plock, the program named Youth Forum on Environmental Policy managed "to raise awareness of the environmental policy in Policy, facilitate cooperation between youth and local government representatives" (p. 121) for the high-school students and teachers during 2000-2001.

Probably the most challenging aspect of sustainability is to transform it in a collaborative process - where "citizens need to agree upon a vision as well as an action plan for the future" (Manitoba Education and Training, 2000, p. 5). Studies related to environmental policies and waste management show that people have little understanding of the term sustainability, main sources for information being presented by television, and less often by media sources such as radio or magazines (Grodzinska-Jurczak, 2003). Formal education is placed at the end of the list of these information sources. It is shown that local governmental organizations take more care of education for kindergarten children than adults, by "organizing ecological competitions, campaigns for local residents and the production of educational materials for kindergarten teachers and pupils (Grodzinska-Jurczak, 2003, p. 3). Additionally, forms of education for sustainability are introduced at the second and third stages of education, at which teachers of all subjects will be responsible for presenting the material or reaching the educational objectives. Therefore, in a country like Poland, where the level of sustainability awareness is low, it is necessary to educate teachers who are meant to develop knowledge and pro-environmental attitude in students.

In this point of the study, it is noteworthy that NGOs and universities have been identified as main actors providing educational programs with focus on sustainability. NGOs help to alleviate problems like low awareness in Polish society of sustainable development principles and consumption decisions (Kronenberg \& Bergier, 2012) while universities "are expected to be involved with social, technological and environmental issues" (Koscielniak, 2014, p. 114). One example of universities' action in supporting education for sustainability is the MBA program, OneMBA, developed as a partnership between five business schools on four continents (Roome, 2005). The MBA program held a sevenday global residency on Sustainability and Supply-Chain Management, partly based in Gdansk, Poland, with the following objectives: "principles of sustainability in business, the role and contribution of systems thinking to sustainability and its relationship to other information, the importance of developing and retaining local value added in global supply chains" (Roome, 2005, p. 5) The outcomes of this academic exercise revealed the fact that sustainability is a growing issue for the global business, with increasing management problems of environmental and social aspects in Europe. The main result of this residency was that there is no universal approach to sustainability; instead it needs to be adapted to local policies and contexts.

A more recent study informs about the implementation of education for sustainability in three European countries - Germany, France, Poland - counting on social representations gained by students enrolled in a Master program of European Studies (Barthes \& Jeziorski, 2012). The research points out that Polish students are more prone to European Union policies in terms of funding and to sustainability as the collective organization of society towards the resolution of at least one problem to be addressed (rich - poor).

In their effort to develop a common resolution of action to live more sustainably, Lockley and Jarrath (2013) developed a framework for the nature of sustainability. Using the workshops held during a conference as empirical material, the authors organized the framework around four aspects of sustainability: ecological, social, cultural 
and economic. It is revealed that major characteristics for sustainability mentioned in discussions by Polish participants are: ecosystem functions (recycling materials, energy flow) and citizenship (advocacy). Along with the contribution made by NGOs and universities to the subject of education for sustainability, a new phenomenon is observed in Polish society: quiet sustainability. Defined by "practices that result in beneficial environmental or social outcomes, that do not relate directly or indirectly to market transactions" (Smith, \& Jehlicka, 2013), quiet sustainability is characteristic of cultures of sharing, repairing and gifting, such as the Polish one, proving to be able to face dramatic social and economic changes.

However, despite the amount of positive examples presented, researchers report a poor knowledge of sustainable development concepts among Polish society, which understands sustainability as ecology or environmental protection, the most meaningful root cause being attributed to the National Curriculum content (Czapla \& Berlińska, 2011; Koscielniak, 2014; Adomßent et al., 2014)

\section{DISCUSSION}

Although Poland is a European Union member state aligning itself to the European standards, the research reveals a discrepancy between the image promoted by business organizations and their actual actions in promoting and supporting education for sustainability. This discontinuity, known as the de-coupling effect (Yang \& Zheng, 2011), may be caused by the institutional pressure exerted by governmental authorities to adapt to European and United Nations' politics.

Moreover, the deficit of reporting identified in the research shows a lack of transparency on companies' side, leading to mistrust from communities and stakeholders (Scrobota \&Vosylius, 2013). The lack of transparency has consequences for the ability of society to understand the benefits of sustainability and to act accordingly.

Additionally, the paper exposes a common misinterpretation of the term education for sustainability among Poles, being considered as the same as environmental education or ecology. However, despite the negative aspects there is presented a considerable amount of improvements and good directions in the process of educating for sustainability. One important aspect is that collaborations between companies and universities create an organizational learning culture (Tohidi \& Mandegari, 2012), contributing to the welfare of the communities and raising the awareness on sustainability. Moreover, the community-based learning has made possible the emergence of a new phenomenon - quiet sustainability - which nurtures the culture of sharing, repairing and gifting, important for the objectives of sustainability to build a better future.

\section{CONCLUSIONS}

Designed as a narrative literature review, the paper answers the research questions by organizing the available literature into two major themes: education for sustainability in business, and respectively in non-profit organizations. Education for sustainability represents an umbrella for many forms of education and therefore the actors participating in this process have to adapt their methods to the local policies and context. 
In Poland, the main forms of education for sustainability involve education programs and collaborative programs between local communities and institutions, the earliest programs of such kind being initiated by NGOs to address topics such as: sustainable development, ecological education and renewable resources. In the business area, companies focus on education programs for their employees tackling the subjects of ecological awareness, energy saving methods, work-life balance, waste management, or develop partnerships with local institutions to improve the ecological awareness of children and young people. Sustainability reporting, although in its early stages, represents an important tool used by companies to educate their employees on sustainable behavior in and/or out of the workplace.

It is worth mentioning the recent phenomenon of co-operation between business organizations and universities which results in innovative products and increased welfare of the local communities.

Education for sustainability conducted from NGOs' perspective is enabling the cooperation between communities and local government representatives and is promoting local producers and friendly consumption. Additionally NGOs and universities prove to be learning facilitators in the sustainability topic by creating education programs addressed to both Polish and international students.

Referring to the outcomes of education for sustainability and its impact on Polish society, studies reveal a low awareness and understanding of the term sustainability (only 36\% of Poles were able to define correctly the concept of sustainable development), television being a main source of information, while local government institutions are providing more education for children, rather than for adults. A low index of engaging in life-long activities constitutes a cause for the current situation, only every nineteenth adult taking part in further education forms.

Furthermore, it is noticed that scholars attribute the low level of awareness to the weak practices of integrating education programs for sustainability into the education system and National Curriculum.

\section{LIST OF ABBREVIATIONS:}

$\begin{array}{ll}\text { APA } & \text { - American Psychological Association } \\ \text { CBOS } & \text { - Public Opinion Research Center - Polish polling agency } \\ \text { CSR } & \text { - Corporate Social Responsibility } \\ \text { ESD } & \text { - Education for Sustainable Development } \\ \text { ING } & \text { - The ING Group is a Dutch multinational banking and financial } \\ & \text { services corporation headquartered in Amsterdam } \\ \text { MBA } & \text { - Master of Business Administration } \\ \text { NGO } & \text { - Non-governmental organizational } \\ \text { OECD } & \text { - Organization for Economic Co-operation and Development } \\ \text { PR } & \text { - Public Relations } \\ \text { SME } & \text { - Small and medium size enterprise } \\ \text { UNESCO } & \text { - United Nations Educational, Scientific and Cultural Organization }\end{array}$




\section{REFERENCES}

Adomßent, M., Fischer, D., Godemann, J., Herzig, C., Otte, I., Rieckemann, M. \& Timm, J. (2014). Emerging areas in research on higher education for sustainable development e management education, sustainable consumption and perspectives from Central and Eastern Europe. Journal of Cleaner Production, 62, 1-7.

Astupan, A., \& Schönbohm, A. (2012). Sustainability reporting performance in Poland: empirical evidence from the wig 20 and wig 40 companies. Polish Journal of Management Studies, 6, 68-80.

Barthles, A., \& Jeziorski, A. (2012). What Kind of Critical University Education for Sustainable. Journal of Social Science Education, 11(4), 405-417.

Baumeister, R. F., \& Leary, M. R. (1997). Writing Narrative Literature Reviews. Review of General Psychology, 1(3), 311-320.

Blaikie, N. (2003). Analzying Quantitative Data. Thousand Oaks: Sage Publications.

CBOS. (2008). Stowarzyszeniowo-obywatelski kapitat społeczny [Stowarzyszeniowo-civic social capital]. Warsaw: CBOS.

Cipriani, A. \& Geddes, J. (2003). Comparison of systematic and narrative literature reviews: the example of the atypical antipsychotics. Epidemiologia e Psichiatria Sociale, 30(3), 146-154

Cortese, A. (1999). Education for Sustainability - The Need for a New Human Perspective. Second Nature, 1-10.

Council of Ministers. (2002). The National Environmental Policy for 2003 - 2006 and Its 2010 Outlook. Retrieved January 15, 2014, from http:/ / www.mos.gov.pl/g2/big/2009_07/2826c539c3015384e50adac8fe920b0b.pdf.

Council of Ministers. (2008). The National Environmental Policy for 2009- 2012 and Its 2016 Outlook. Retrieved January 15, 2014, from http:// www.mos.gov.pl/g2/big/2009_07/2826c539c3015384e50adac8fe920b0b.pdf.

Cronin, P., Ryan, F., \& Coughlan, M. (2008). Article: Undertaking a literature review: a step-by-step approach. British Journal of Nursing, 17(1), 38-43.

Czapla, M., \& Berlińska, A. (2011). Perspectives of Education for Sustainable Development - Understanding and Introduction the Notion in Polish Educational Documents. Discourse and Communication for Sustainable Education, 2(1), 56-67.

Czarski, E. (2011). Sustainable Development Indicators for Poland - Developing and implementing a Polish set of SD indicators, Statistical Office in Katowice. Retrieved January 10, 2014, from http:/ / www.stat.gov. $\mathrm{pl} / \mathrm{cps} / \mathrm{rde} / \mathrm{xbcr} / \mathrm{gus} /$ as_Sustainable_Development_Indicators_for_Poland.pdf

De la Motte, R. (2007). A Tale of Two Cities: Public participation and sustainability in decision-making on water systems in two Polish cities. Utilities Policy, 15, 134-142.

Elsevier. (2014). A guide for writing scholarly articles or reviews for the Educational Research Review. Retrieved January 26, 2014, from http://www.elsevier.com/_data/promis_misc/edurevReviewPaperWriting.pdf

Grigoroudisa, E., Kouikogloua, V. S., \& Phillis, Y. A. (2013). SAFE 2013: Sustainability of countries updated. Ecological Indicators, 38, 61-66.

Grodzinska-Jurczak, M. (2003). The relation between education, knowledge and action for better waste management in Poland. Waste Management and Research, 11(2), 1-18.

Hąbek, P. (2013). Evaluation of sustainability reporting practices in Poland. Quality \& Quantity, 48(3), 1739-1752.

ING. (2012). The art of Responsibility - CSR Report 2011- 2012. Retrieved January 15, 2014, from http:// en.ingbank.pl/company-profile/corporate-social-responsibility

Institute for Sustainable Communities. (2001). Community-based approach to education for sustainability developing a new generation of leaders through school-based programs linked to community issues. Retrieved December 20, 2013, from http://www.iscvt.org/who_we_are/publications/Education\%20for $\% 20$ Sustainability\%20Guidebook.pdf.

Krippendorff, K. (1980) Content Analysis: an introduction to its methodology, Thousand

Oaks: Sage Publications

Koscielniak, C. (2014). A consideration of the changing focus on the sustainable development in higher education in Poland. Journal of Cleaner Production, 62, 114-119. 
Journal of Education Culture and Society No. 2_2014

Kronenberg, J., \& Bergier, T. (2012). Sustainable development in a transition economy: business case studies from Poland. Journal of Cleaner Production, 26, 18-27.

Lockley, J., \& Jarrath, M. (2013). The Nature of Sustainability as Viewed by European Students. Journal of Education for Sustainable Developmen, 7(1), 113-124.

Manitoba Education and Training. (2000). Education for a Sustainable Future A Resource for Curriculum Developers, Teachers, and Administrators. Retrieved December 20, 2013, from http:/ / www.edu.gov.mb.ca/ k12/docs/support/future/sustaineducation.pdf .

McMillan, J. H., \& Schumacher, S. (1993). Research in education: A conceptual understanding. New York: HaprerCollins.

Nowaczek, A., \& Fennell, D. A. (2002). Ecotourism in post-communist Poland: An examination of tourists, sustainability and institutions. Tourism Geographies, 4 (4), 372-395.

OECD. (2006). Good Practices in the National Sustainable Development Strategies of OECD Countries. Sustainable Development Studies. Retrieved December 24, 2013, from http://www.oecd.org/ greengrowth/36655769.pdf.

Patton, M. Q. (1990). Qualitative Evaluation and Research Methods (2nd ed.). Newbury Park,

CA: Sage Publications, Inc.

Pawłowski, A. (2013). Sustainable Development and Globalization. Problems of Sustainable Development, 8(2), 5-16.

Phillis, Y. A., Grigoroudis, E., \& Kouikoglou, V. S. (2011). Sustainability ranking and improvement of countries. Ecol. Econ, 70, 542-553.

Platje, J. (2011). The level of institutional capital and challenges in sustainable development. Economic and Environmental Studies, 11(1), 99-116.

Poland. Polish parliament. (1997). The Constitution of the Republic of Poland. Retrieved December 15, 2013, from http://isap.sejm.gov.pl.

Responsible Business Forum.(2010). Responsible Business in Poland. Good practices Report. Retrieved February 26, 2014, from http://odpowiedzialnybiznes.pl/public/files/GoodPracticesinPolandReport_RBF_2011.pdf .

Roome, N. (2005). Teaching Sustainability in a Global MBA: Insights from the OneMBA. Business Strategy and the Environment, 14(3), 160-171.

Rother, E.A. (2007). Systematic literature review X narrative literature review, Acta Paulista de Enfermagem, 20(2), vii-viii.

RWE Polska. (2011). Sustainable Development RWE In Poland. Report 2011. Retrieved February 26, 2014, from http://www.rwe.com/web/cms/mediablob/en/1510230/data/1715170/1/rwe-generation-se/csr/crreports/RWE-in-Poland-Sustainable-Development-Report-2011.pdf.

Science Marketing. (2011). 30 good practice case studies in university-business. Retrieved January 10, 2014, from http://www.ub-cooperation.eu/index/casestudy.

Scrobota, M., \& Vosylius, E. (2013). How Employees Experience Sustainability in the Workplace: A Phenomenological Approach - Master thesis. Malmoe University.

Sendzimir, J. (2010). Challenges of Sustainable Development in Poland. Krakow: Sendzimir Foundation.

Smith, J., \& Jehlicka, P. (2013). Quiet sustainability: Fertile lessons from Europe's productive Gardeners. Journal of Rural Studies, 32, 148-157.

Tohidi, H., \& Mandegari, M., (2012). Assessing the impact of organizational learning capability on firm innovation. African Journal of Business Management, 6(12), 4522-4535.

UNESCO. (2007). Good Practices in the UNECE region, UNESCO Education Sector. Retrieved February 7, 2014, from http:// unesdoc.unesco.org/images/0015/001533/153319e.pdf.

UNESCO. (2005). Guidelines and recommendations for reorienting teacher education to address sustainability. Retrieved February 10, 2014, from http://unesdoc.unesco.org/images/0014/001433/143370E.pdf .

United Nations. (1987). Our common future - Report of the World Commission on Environment and Development. Retrieved January 2, 2014, from http://conspect.nl/pdf/Our_Common_Future-Brundtland_ Report_1987.pdf. 
United Nations. (2009). Learning from each other - The UNECE Strategy for Education for Sustainable Development, United Nations Economic Commission for Europe. Retrieved January 15, 2014, from http:/ / www.unece.org/ env/esd/welcome.htm.

United Nations. (2012). Building A Better, Fairer World for the $21^{\text {st }}$ Century. Retrieved January 2, 2014, from http://www.unesco.org/.

United Nations. (2012). Shaping the Education of Tomorrow - 2012 Report on the UN Decade of Education for Sustainable Development, United Nations Educational, Scientific and Cultural Organization. Retrieved January 5, 2014, from http://unesdoc.unesco.org/images/0021/002166/216606e.pdf .

Yang, S., \& Zheng, L. (2011). The paradox of de-coupling: A study of flexible work program and workers' productivity. Social Science Research, 40, 299-311.

Zieschank, R. (2004). Poland Case Study Analysis of National Strategies for Sustainable Development. Retrieved January 4, 2014, from http://www.iisd.org/ measure/capacity/sdsip.asp. 